\title{
Evaluarea antropometrică şi metabolică pe termen lung a nou-născuților cu restricție de creştere intrauterină fără patologie în perioada neonatală
}

\author{
Mariana-Lăcrămioara Bucur-Grosu' ${ }^{1}$, Andreea-Luciana Avasiloaiei², \\ Mihaela Moscalu ${ }^{3}$, Cristina Dimitriu ${ }^{4}$, Maria Stamatin ${ }^{2}$ \\ ${ }^{1}$ Universitatea de Medicină şi Farmacie „Grigore T. Popa“, Iaşi, România \\ ${ }^{2}$ Neonatologie, Departamentul Medicina Mamei şi Copilului, \\ Universitatea de Medicină şi Farmacie „Grigore T. Popa“, Iaşi, România \\ ${ }^{3}$ Informatică Medicală şi Biostatistică, Departamentul de Medicină Preventivă şi Interdisciplinaritate, \\ Universitatea de Medicină şi Farmacie „Grigore T. Popa“, Iaşi, România \\ ${ }^{4}$ Biochimie, Departamentul de Ştiinţe Morfo-Funcţionale, \\ Universitatea de Medicină şi Farmacie „Grigore T. Popa“, Iaşi, România
}

\begin{abstract}
REZUMAT
Introducere. Greutatea la naştere rămâne cel mai important indice antropometric al nou-născutului. Restricţia de creştere intrauterină (RCIU) stă la baza mortinatalităţii, dar şi la baza afecţiunilor metabolice şi cardiovasculare la adult. În acest studiu este evaluată relaţia între restricţia de creştere intrauterină, dezvoltarea antropometrică şi dinamica unor parametri ai sindromului metabolic până la vârsta de cinci ani.

Material şi metodă. Studiul s-a desfăşurat pe o perioadă de 4 ani (2010-2013) pe un lot de 622 de nou-născuţi cu RCIU fără patologie în perioada neonatală. Starea de nutriție s-a evaluat prin determinarea greutății, taliei, indicelui de masă corporală (IMC) cu încadrarea valorilor obţinute pe curbele de creştere în funcţie de vârstă şi sex propuse de Organizaţia Mondială a Sănătăţii şi a fost comparată cu statusul nutriţional al unui lot de 627 nou-născuţi cu RCIU internaţi în Terapie Intensivă Neonatală. Valorile trigliceridelor şi glicemiei preprandiale au fost evaluate şi comparate cu valorile normale pentru vârstă.

Rezultate. Incidenţa obezităţii (16.1\%) este semnificativ crescută ( $22=32,23, p<<0,01,95 \% \mathrm{Cl}) .57,6 \%$ dintre subiecţi au indice de masă corporală peste limita normală, iar incidenţa supraponderalităţii creşte odată cu vârsta (29\% la 2 ani versus $56,7 \%$ la 5 ani). Incidenţa obezităţii scade odată cu creşterea vârstei $(32,9 \%$ la 2 ani vs. $9,1 \%$ la 5 ani). În ceea ce priveşte sindromul metabolic, $18 \%$ dintre subiecţi au prezentat hiperglicemie, iar valorile colesterolului şi trigliceridelor $(f=10,34, p=0,00001,95 \% \mathrm{Cl})$ cresc odată cu vârsta. $32,8 \%$ dintre copii au prezentat valori ale colesterolului mai mari decât pragul maxim al intervalului normal de $170 \mathrm{mg} / \mathrm{dl}$.

Concluzie. Incidenţa supraponderalităţii şi obezităţii este mai mare în lotul de nou-născuţi cu RCIU faţă de populaţia generală. Este necesară stabilirea relaţiei dintre obiceiurile alimentare şi parametri studiaţi, relaţie care ar putea elucida trendul ascendent al greutăţii şi parametrilor biochimici (trigliceride şi colesterol) în rândul populaţiei incluse în studiu.
\end{abstract}

Cuvinte cheie: restricţie de creştere intrauterină, obezitate, supraponderalitate, sindrom metabolic, nou-născut

\section{INTRODUCERE}

Greutatea la naştere este un indicator de evaluare clinică esențial în rândul nou-născuților. Greutatea şi lungimea sunt expresia dezvoltării intrauterine a fătului ca rezultat al celor trei factori importanți: materni, fetali şi placentari. Aceşti doi parametri au fost mereu folosiţi pentru a identifica nou-născuții cu un potențial risc în apariția complicațiilor în perioada neonatală.

Malnutriția intrauterină este cauza dimensiunii scăzute la naştere, atât în ceea ce priveşte talia, cât şi greutatea şi influențează dezvoltarea ulterioară în copilărie cu urmări asupra sănătătii adultului (1).

Dacă malnutriției i se asociază metode agresive de alimentație, creşterea postnatală poate duce une- 
ori la obezitate şi afecțiuni cardiovasculare şi sindrom metabolic la adult. Această ipoteză este cunoscută ca programarea fetală a afecțiunilor adultului.

Această ipoteză descrisă de Barker în 1988 demonstrează o puternică asociere între greutatea mică la naştere şi creșterea incidenței obezității, hipertensiunii arteriale, diabetului zaharat de tip 2 şi a afecțiunilor cardiovasculare în rândul adulților care au fost afectați de restricție de creştere intrauterină (RCIU) în perioada fetală. Aceasta demonstrează importanța creşterii şi dezvoltării postnatale a nou-născuților cu RCIU şi ajută la stabilirea strategiilor de prevenție şi reducere a incidenței acestor afecțiuni la adult.

Scopul studiului este de a evalua relaţia dintre RCIU şi creşterea şi dezvoltarea copiilor până la vârsta de cinci ani prin determinarea taliei, greutății şi a complicațiilor metabolice la copiii cu RCIU fără complicații neonatale.

\section{MATERIAL ŞI METODĂ}

Am efectuat un studiu prospectiv în cadrul Spitalului Clinic de Obstetrică și Ginecologie „CuzaVodă“ în Iaşi, România, pe un lot de 622 nou-născuți cu RCIU, născuți în perioada 2010-2013 care nu au prezentat patologie în perioada neonatală şi un lot de 627 nou-născuți cu RCIU cu patologie postnatală, care au fost internaţi în Centrul Regional de Terapie Intensivă Neonatală în aceeaşi perioadă, utilizat pentru compararea dinamicii nutriţionale.

$\mathrm{Au}$ fost excluşi din studiu nou-născuții cu malformații congenitale şi nou-născuții proveniți din sarcini gemelare.

$\mathrm{Au}$ fost evaluați următorii parametri în cazul ambelor loturi: vârsta de gestaţie, greutatea la naştere, talia la naştere, sexul, indicele de masă corporală, iar în cazul lotului de nou-născuți fără patologie: valorile glicemiei, trigliceridelor, colesterolului la copiii cu vârste cuprinse între 2 şi 5 ani.

RCIU a fost definită ca greutatea la naştere situată sub percentila 3 pe curbele de creştere intrauterină (4).
Evaluarea stării de nutriție s-a facut prin determinarea greutăţii şi a taliei şi a calculării IMC (indice de masă corporală $)=\mathrm{G}(\mathrm{kg}) / \mathrm{T}(\mathrm{m})$ şi încadrarea lor pe curbele de creştere în funcție de vârstă şi sex propuse de Organizația Mondială a Sănătății (5) (Tabelul 1).

Profilul metabolic a fost evaluat prin determinarea nivelului plasmatic al glucozei, trigliceridelor şi colesterolului prin metoda biochimiei umede, cu ajutorul analizorului RX Daytona+ ${ }^{\circledR}$ (Randox Laboratories Ltd., Crumlin, County Antrim, UK).

Valorile trigliceridelor şi glicemiei preprandiale au fost evaluate după valorile publicate în workshopul Federației Internaționale de Diabet (IDF) în 2007 și definit ca valori ale trigliceridelor mai mari de $150 \mathrm{mg} / \mathrm{dl}$, glicemie mai mare de $110 \mathrm{mg} / \mathrm{dl}$ (6).

Analiza statistică a fost efectuată cu ajutorul programului SPSS, versiunea 20, utilizând teste parametrice. Parametrul de referință $p$ reprezintă nivelul de semnificație a testului care a fost comparat cu valoarea prag de 0,05 , ceea ce corespunde unui interval de încredere $95 \%$. Rezultatele au fost considerate semnificative statistic la o valoare $\mathrm{a}<0,05$.

\section{REZULTATE}

Pe parcursul a 4 ani în Spitalul Clinic de Obstetrică-Ginecologie „Cuza-Vodă“, numărul total de naşteri a fost de 24007, dintre care $1.249(5,2 \%)$ au fost diagnosticați cu RCIU.

În lotul studiat au fost incluşi nou-născuți cu greutatea situată între 2.100 şi 2.950 grame şi talia cu valori cuprinse între 45 şi $52 \mathrm{~cm}$ (Tabelul 2). Rezultatele au evidențiat o frecvență mai mare $(62,38 \%)$ a nou-născuților RCIU de sex feminin $\left(\chi^{2}=9,55, p=0.002,95 \% \mathrm{CI}\right)$.

Evaluarea statusului nutrițional între 2-5 ani a arătat că prevalența obezității în rândul nou-născuților fără patologie neonatală $(16,1 \%)$ a fost semnificativ crescută în comparație cu grupul celor cu patologie neonatală $-4,8 \%\left(\chi^{2}=32.23, \mathrm{p}<<0.01\right.$, $95 \% \mathrm{CI})$. De asemenea, se remarcă un procent ridicat de cazuri $(57.6 \%)$ cu IMC peste limita normală în cazul nou-născuților RCIU fără patologie. În cazul acestora, rezultatele arată o creştere a prevalen-

TABELUL 1. Definirea obezității şi supraponderalității în funcție de indicele de masă corporală pentru vârstă şi sex

\begin{tabular}{|l|c|c|c|c|}
\hline & Sex & $\mathbf{2}$ ani & $\mathbf{3}$ ani & $\mathbf{4}$ ani \\
\hline \multirow{3}{*}{ Supraponderalitate } & $F$ & $\mathrm{IMC}=18-18,6$ & $\mathrm{IMC}=17,1-18,3$ & $\mathrm{IMC}=16,8-18,4$ \\
\cline { 2 - 5 } & $\mathrm{M}$ & $\mathrm{IMC}=18,1-18,7$ & $\mathrm{IMC}=17,4-18,4$ & $\mathrm{IMC}=17-18,1$ \\
\hline \multirow{2}{*}{ Obezitate } & $F$ & $\mathrm{IMC}>18,7$ & $\mathrm{IMC}>18,4$ & $\mathrm{IMC}>18,5$ \\
\cline { 2 - 5 } & $\mathrm{M}$ & $\mathrm{IMC}>18,8$ & $\mathrm{IMC}>18,5$ & $\mathrm{IMC}>18,2$ \\
\hline
\end{tabular}


TABELUL 2. Indicatorii statistici ai parametrilor la naştere

\begin{tabular}{|l|c|c|c|c|c|c|c|c|c|c|}
\hline \multirow{2}{*}{} & \multirow{2}{*}{ Media } & \multicolumn{2}{|c|}{ Media } & \multirow{2}{*}{ DS } & \multirow{2}{*}{ ES } & Min & Max & \multirow{2}{*}{ Q25 } & Mediana & \multirow{2}{*}{ Q75 } \\
\cline { 3 - 9 } & & $-95 \%$ & $-95 \%$ & & & & & & \\
VG (s) & 39,3 & 39,2 & 39,4 & 1,0 & 0,0 & 37,0 & 42,0 & 39,0 & 39,0 & 40,0 \\
\hline GN (g) & 2614.8 & 2605.4 & 2624.3 & 120.4 & 4.8 & 2100 & 2950 & 2550 & 2600 & 2700 \\
\hline T (cm) & 48.60 & 48.50 & 48.71 & 1.33 & 0.05 & 45.00 & 52.00 & 48.00 & 49.00 & 50.00 \\
\hline
\end{tabular}

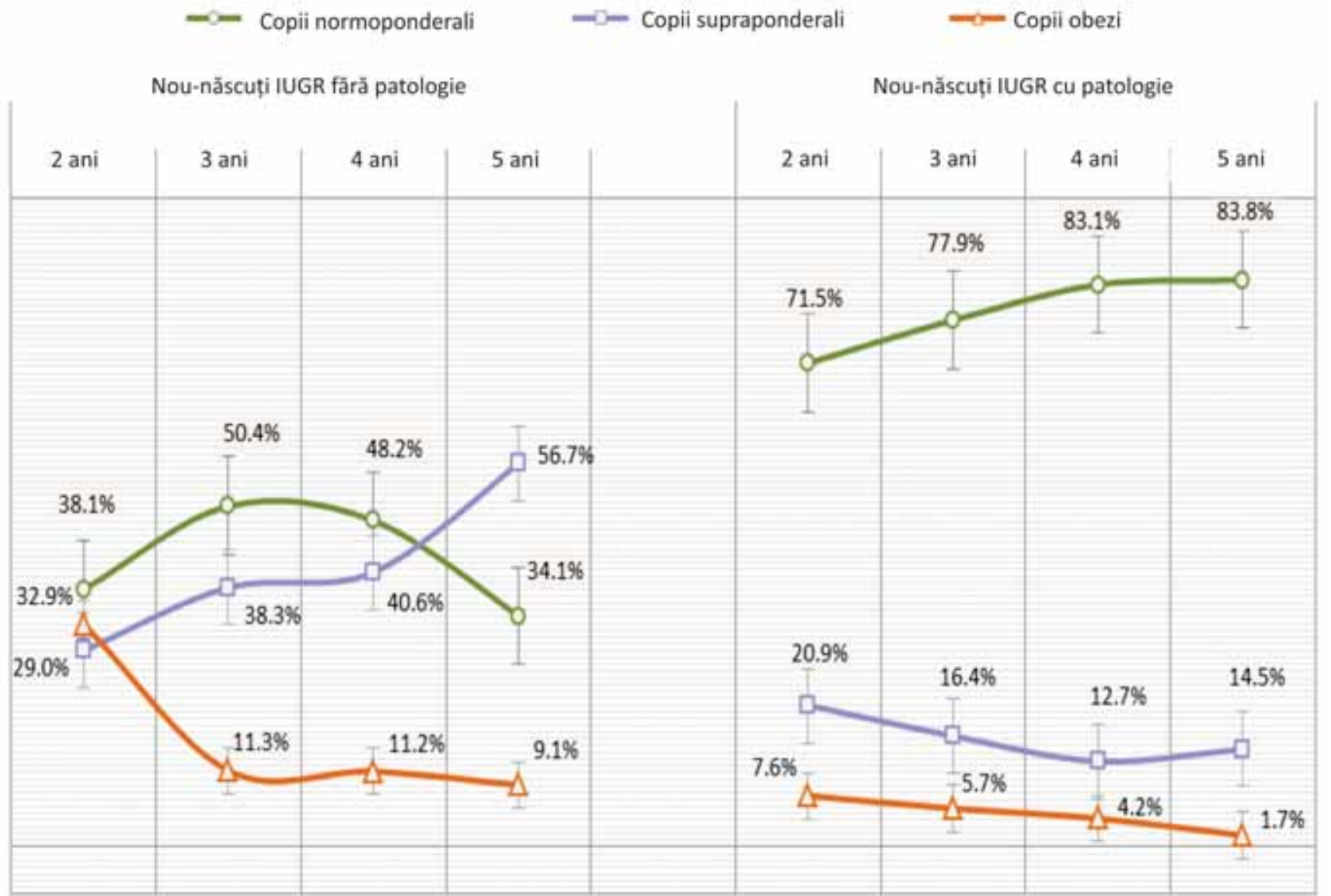

FIGURA 1. Evaluarea stării de nutriție în loturile analizate în funcție de vârsta la momentul evaluării

ței supraponderalității odată cu vârsta: de la 16\% la vârsta de 2 ani la $56,7 \%$ la 5 ani dar cu o scădere a prevalenței obezității în același timp (32,9\% la 2 ani vs $9,1 \%$ la 5 ani) (Fig. 1). În cazul nou-născuţilor RCIU cu patologie neonatală, procentul celor cu IMC crescut este de 18,1\%, observându-se scăderea în timp atât a incidenței obezităţii (de la 7,6\% la 2 ani la $1,7 \%$ la 5 ani), cât şi a supraponderalității (20,9\% la 2 ani vs $14,5 \%$ la 5 ani).

Din analiza valorilor IMC la copiii cu RCIU fără patologie în perioada neonatală, rezultă faptul că $43.4 \%$ din copii prezintă valori peste limita nor- mală a IMC. Valoarea medie a fost de 16,8土1,54 DS cu valori minime şi maxime aflate în intervalul 11.1 şi 25 (Tabelul 3).

La vârsta de 2 ani, IMC are valori situate în intervalul 13,5 şi 25 , cu o medie de 17,7. Pe parcursul următorilor doi ani, IMC scade, prezentând o nouă creştere spre vârsta de 5 ani. În lotul de studiu, supraponderalitatea s-a dublat de la vârsta de 2 ani la 5 ani, iar prevalența obezității a scăzut. IMC are o valoare crescută la vârsta de 2 ani, înregistrând apoi o tendință descrescătoare cu vârsta $(\mathrm{F}=14,52$, $\mathrm{p}<<0,01,95 \%$ CI) (Fig. 2).

TABELUL 3. Indicatorii statistici ai IMC la copiii cu RCIU fără patologie postnatală

\begin{tabular}{|l|c|c|c|c|c|c|c|c|c|}
\hline \multirow{2}{*}{$\begin{array}{l}\text { Media } \\
\text { IMC }\end{array}$} & \multicolumn{2}{|c|}{ Media } & \multirow{2}{*}{ Dev.std } & Er.std & Min & Max & Q25 & Mediana & Q75 \\
\cline { 2 - 9 } & $-95 \%$ & $-95 \%$ & & & & & \\
\hline 16,82 & 16,63 & 17,01 & 1,54 & 0,10 & 11,10 & 25,00 & 15,80 & 16,80 & 17,60 \\
\hline
\end{tabular}


Categ, Box \& Whisker Plot: IMC

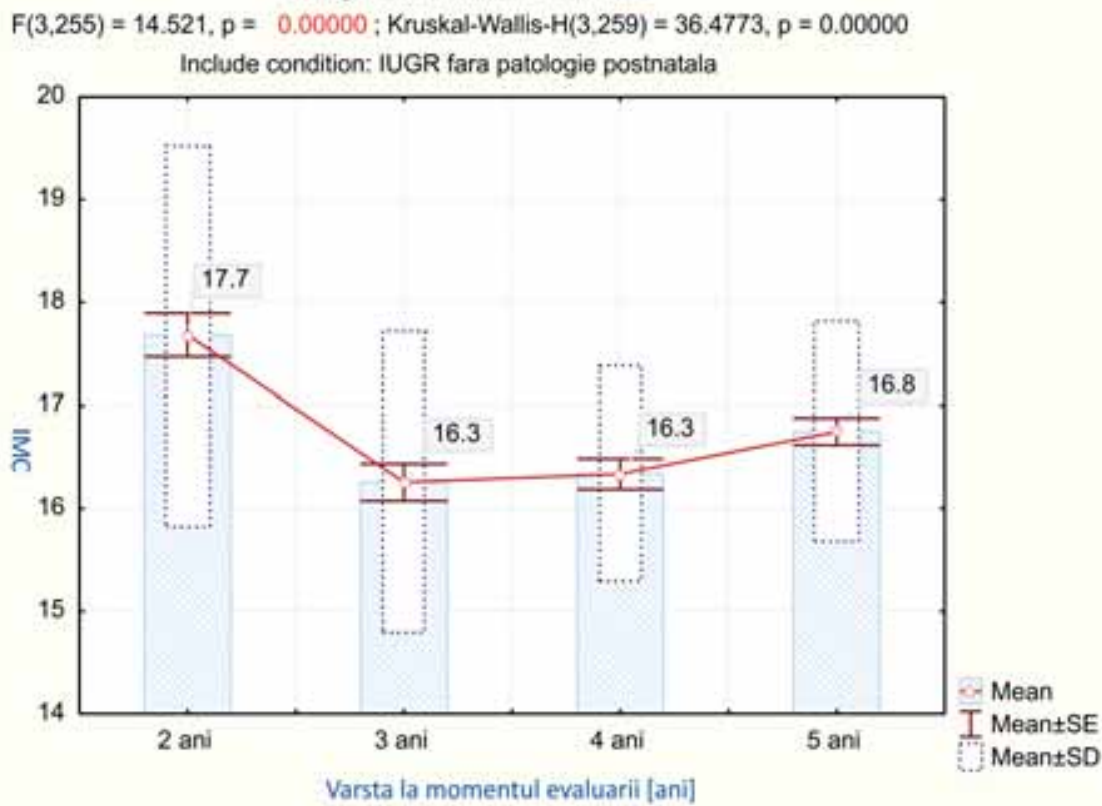

FIGURA 2. Distribuția IMC pe vârstă

TABELUL 4. Indicatorii statistici ai parametrilor biochimici la copiii cu RCIU fără patologie postnatală

\begin{tabular}{|l|c|c|c|c|c|c|c|c|c|c|}
\hline \multirow{2}{*}{ lot } & \multirow{2}{*}{ Media } & \multicolumn{2}{|c|}{ Media } & \multirow{2}{*}{ DS } & \multirow{2}{*}{ ES } & Min & \multirow{2}{*}{ Max } & \multirow{2}{*}{ Q25 } & \multirow{2}{*}{ Mediana } & \multirow{2}{*}{ Q75 } \\
\cline { 3 - 8 } & & $-95 \%$ & $-95 \%$ & & & & & & & \\
\hline Glicemie & 87.3 & 84.9 & 89.7 & 10.6 & 1.2 & 70.0 & 123.0 & 79.5 & 88.0 & 92.0 \\
\hline Trigliceride & 59.5 & 53.5 & 65.5 & 25.9 & 3.0 & 29.0 & 150.0 & 43.0 & 48.0 & 67.0 \\
\hline Colesterol & 144.5 & 136.9 & 152.1 & 32.6 & 3.8 & 100.0 & 197.0 & 110.0 & 144.0 & 178.0 \\
\hline
\end{tabular}

Nivelul plasmatic al trigliceridelor creşte semnificativ în rândul nou-născuților cu RCIU fără patologie neonatală. De asemenea, nivelul colesterolului creşte semnificativ după vârsta de 3 ani, valorile medii situându-se la limita maximă a intervalului de valori normale $(170 \mathrm{mg} / \mathrm{dl})$.

Majoritatea copiilor investigați a prezentat valori ale glicemiei situate în intevalul valorilor nor-

Categ. Box \& Whisher Plot: Glicemie

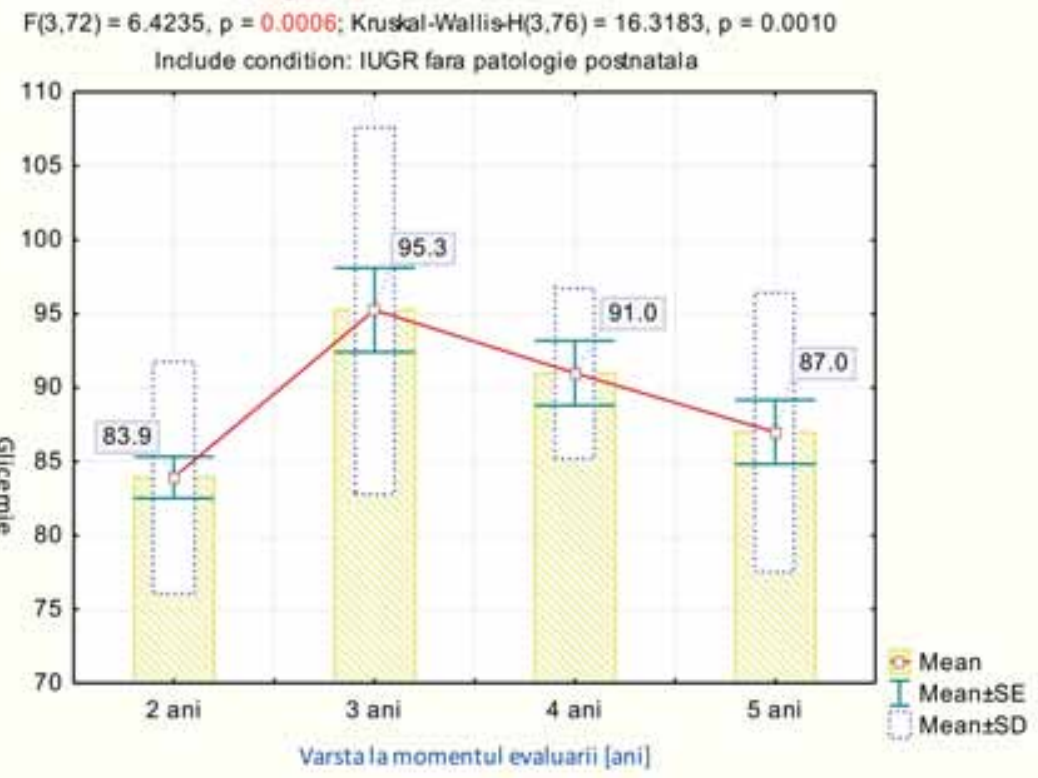

FIGURA 3. Valorile medii ale glicemiei la copiii cu RCIU fără patologie postnatală 


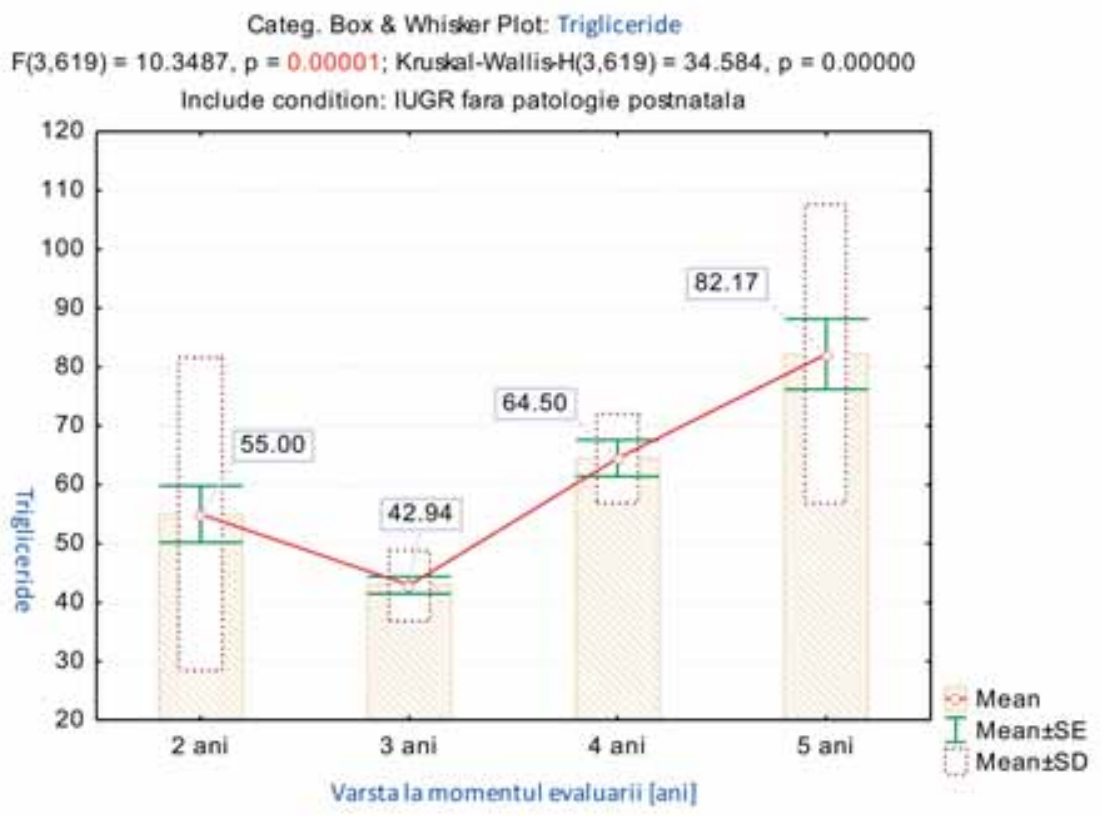

FIGURA 4. Valorile medii ale trigliceridelor la copiii cu RCIU fără patologie postnatală

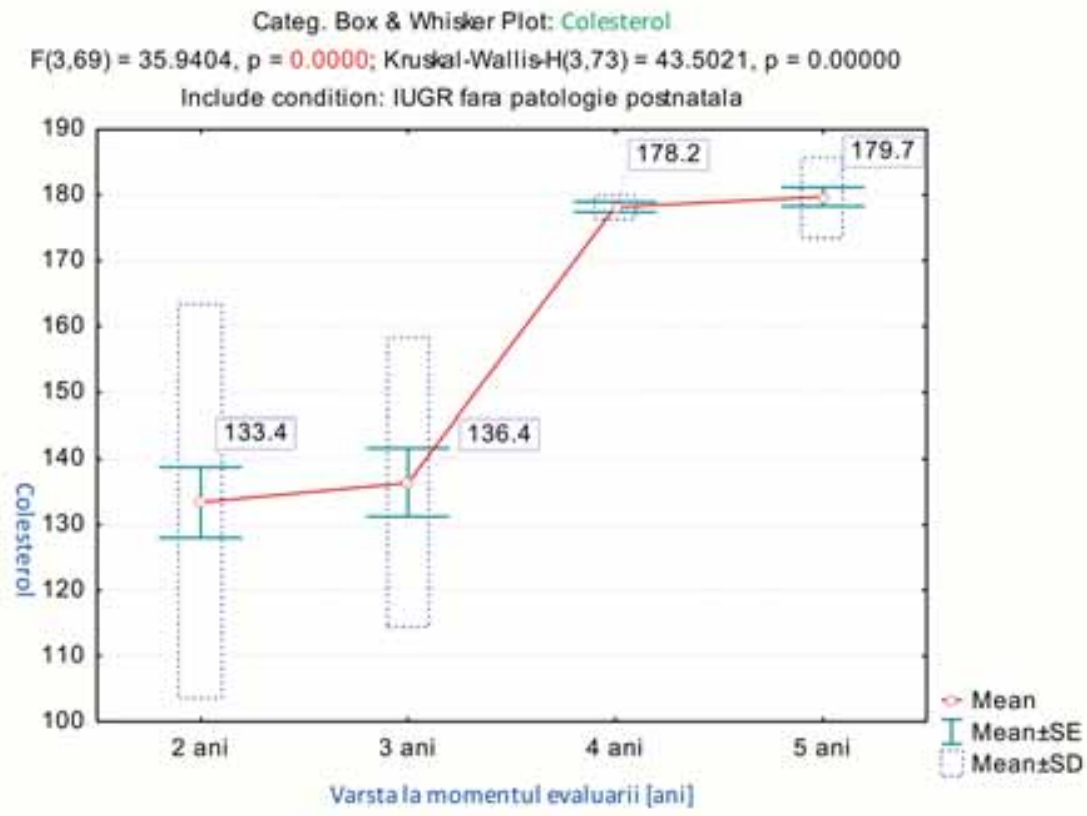

FIGURA 5. Valorile medii ale colesterolului la copiii cu RCIU fără patologie postnatală

male $(80-100 \mathrm{mg} / \mathrm{dl}) .18 \%$ dintre nou născuții cu RCIU fără patologie neonatală au prezentat hiperglicemie, iar 2,5\% dintre cazuri au avut valori la limita inferioară a intervalului $(70 \mathrm{mg} / \mathrm{dl})$. Valoarea maximă a glicemiei, dar situată în intervalul valorilor normale, s-a înregistrat în rândul copiilor cu vârsta de 3 ani, aceste valori înregistrând o scădere până la vârsta de 5 ani (Fig. 3).

Intervalul de valori ale trigliceridelor cu cea mai mare incidență în lotul de studiu au fost incluse în intervalul 40-65 mg/dl. 13,8\% dintre copiii cu RCIU fără patologie neonatală au prezentat valori ale trigliceridelor mai mari de $80 \mathrm{mg} / \mathrm{dl}$. Valorile cele mai scăzute au fost înregistrate la copiii de 3 ani $(43 \mathrm{mg} / \mathrm{dl})$, dar cu tendința de dublare a valorilor odată cu creşterea în vârstă, până la 5 ani $(82$ $\mathrm{mg} / \mathrm{dl})$. Această creştere este statistic semnificativă $(\mathrm{F}=10,34, \mathrm{p}=0,00001,95 \% \mathrm{CI})$ (Fig. 4).

În cazul colesterolului, 32,8\% dintre copiii studiați au avut valori ale colesterolemiei mai mari de $170 \mathrm{mg} / \mathrm{dl}$. Valoarea medie a înregistrat minime la vârsta de 2 şi 3 ani, dar a crescut semnificativ (F35,94, p <<0,001) cu mai mult de $40 \mathrm{mg} / \mathrm{dl}$, la vârstele de 4 şi 5 ani (Fig. 5). 


\section{DISCUŢII}

Incidența nou-născuților cu RCIU în lotul studiat este de 5,2\% şi se încadrează în intervalul înregistrat în Europa (între 4,6\% şi 15,3\%) (7-12). RCIU are multipli factori de risc care pot fi modulați intrauterin: predispoziția genetică, statusul nutrițional matern preconcepțional şi creşterea ponderală maternă în cursul sarcinii, statusul socioeconomic, consumul matern de alcool și tutun sau prezența poluanților atmosferici (13). În ciuda profilaxiei RCIU, incidența acesteia ramâne constantă, iar consecințele pe termen lung pot fi serioase.

Incidența copiilor supraponderali creşte odată cu vârsta în studiul nostru, ajungând de la 29\% la vârsta de 2 ani la 56,7\% la 5 ani, însă se constată scăderea incidența copiilor obezi odată cu creşterea vârstei (32,9\% la 2 ani vs. 9,1\% la 5 ani). În cadrul unui studiu recent pe copii în vârstă de 8 ani prevalența obezității şi a supraponderalității a fost de 27,75\% (14).

Există deci posibilitatea ca o mare pondere din copii supraponderali şi obezi să provină din nounăscuții cu RCIU, incidența supraponderalității de la 2 la 5 ani dublându-se în rândurile acestei populații, comparativ cu copiii fără RCIU. Având în vedere scăderea procentului de copii obezi odată cu vârsta în cazul lotului studiat, putem sugera că obezitatea este influenţată şi de alţi factori cum ar fi: stilul de viață, obiceiurile alimentare, date care nu au fost incluse în studiul de față. Ca o particularitate a țării noastre, și în rândul populației adulte, România este singurul stat al Uniunii Europene a cărui populație supraponderală încadrată până la vârsta de 64 de ani nu devine obeză după această vârstă, în cazul celorlalte țări ale UE incidența populației obeze crescând o dată cu înaintarea în vârstă (6). În literatura de specialitate se demonstrează asocierea între supraponderalitate şi obezitate la vârste mai mici de 5 ani şi supraponderalitate şi obezitate la adult, fiind subliniată influența negativă a indicilor antropometrici crescuți de la vârsta de 2 ani şi relația de cauzalitate directă a acestora cu obezitatea la adult $(15,16)$.
18\% dintre subiecții studiați au avut valori ale glicemiei care s-au situat la limita superioară a limitei normale, iar la 2,57\% dintre subiecți s-au înregistrat valori la limita inferioară. Pe parcursul studiului, niciunul dintre subiecți nu a fost diagnosticat cu diabet zaharat tip 1 .

Hiperglicemia este unul dintre cei mai importanţi factori de comorbiditate care, prezent încă din copilărie, creşte riscul mortalității la adultul tânăr alături de obezitate (6).

Colesterolul seric şi trigliceridele au prezentat în studiul nostru valori aflate în limite normale, înregistrând însă o creştere odată cu vârsta subiecților. Studii efectuate pe populații de la vârsta de adolescent până la vârsta adultă nu demonstrează o corelație directă între valorile crescute ale acestor doi parametri şi mortalitatea precoce, dar aceştia pot juca un rol esențial în creşterea incidenței afecțiunilor cardiace (17-19).

\section{CONCLUZII}

Incidența supraponderalității şi a obezității în rândul copiilor proveniți din nou-născuți cu RCIU este crescută față de incidența în populația largă de copii şi creşte odată cu vârsta.

În intervalul de 2-5 ani, valorile glicemiei nu înregistrează o creştere concomitentă cu vârsta. În ceea ce priveşte valorile colesterolului şi ale trigliceridelor, se înregistrează o creştere odată cu vârsta, dar valorile se situează în intervalul de referință al normalului.

Este necesară extinderea perioadei de studiu până la adolescență cel puțin pentru a putea fi urmărită evoluția acestor subiecți şi pentru a putea fi urmărite apariția complicațiilor precoce din cadrul sindromului metabolic.

Obezitatea şi sindromul metabolic sunt reglate epigenetic, pornind de la nutriția in utero şi continuând cu alimentația postnatală, din perioada de sugar şi copil mic. Se impune astfel stabilirea relației dintre obiceiurile alimentare ale copilului şi parametrii biochimici studiați. 